\title{
Erich Wasmann, S.J.: Natural Species and Catholic Polyphyletic Evolution during the Modernist Crisis
}

\author{
James R. Hofmann \\ Collegeville Institute for Ecumenical and Cultural Research \\ jhofmann@fullerton.edu
}

\begin{abstract}
During the first half of the twentieth century, "natural species" played a prominent role in Catholic efforts to accommodate evolutionary biology within the neo-Scholastic theology of the age. Particularly during the modernist crisis early in the century, the most influential figure in this development was the Jesuit entomologist and evolutionary theorist Erich Wasmann (1859-1931). The anti-modernist context in which Wasmann worked included two cases involving evolution that were decided by the Congregation of the Index while Franz Xaver Wernz (1842-1914), Wasmann's future Jesuit superior general (1906-14), served as a consultor. I describe Wasmann's introduction of the natural species concept against this background and analyze his decision to abide by Wernz's warning with respect to human evolution. I then provide examples of how Wasmann's reliance upon natural species and polyphyletic evolution was adopted in subsequent Catholic efforts to reach a synthesis of theology and evolutionary biology.
\end{abstract}

\section{Keywords}

Erich Wasmann - theistic evolution - modernism - polyphyletic evolution - natural species - Jesuit science

1 A preliminary version of this paper was presented at the 2018 meeting of the American Catholic Philosophical Association where helpful commentary was provided by Peter Distelzweig and Kenneth Kemp.

(C) JAMES R. HOFMANN, 2020 | DOI:10.1163/22141332-00702006

This is an open access article distributed under the terms of the prevailing CC-BY-NC-ND 4.0 license. 
Erich Wasmann's most prominent efforts to reconcile his scientific research with Catholic theology took place during the height of the "modernist crisis" in the first decade of the twentieth century. Historians have reached a broad consensus that modernism, as a label for a set of suspect theological attitudes and methodologies, was largely the creation of Pius X during his 1903-14 papacy. One of his fears was that an emphasis upon religious experience rather than codified doctrine would encourage an understanding of both Scripture and doctrine as historically situated and subject to variable interpretations. In 1909, the Pontifical Biblical Commission issued a decree that proscribed calling into doubt "the literal, historical sense" of Genesis $1-3 .{ }^{2}$ Although the Vatican issued no doctrinal pronouncements on evolution as such, its conservative insistence upon traditional interpretations of Genesis discouraged discussion of evolutionary alternatives, especially involving human evolution. Wasmann's publications on this topic would be curtailed by his Jesuit superior general, Franz Xaver Wernz.

Prior to serving as the twenty-fifth Jesuit superior general from 1906 to 1914, Wernz specialized in canon law and rose quickly within the Roman curia, closely supported by Pius X(r.1903-14). His association with the pope was in fact so close that there is some symbolism in the fact that he died mere hours prior to the death of the pope himself. ${ }^{3}$ Wernz taught at the Pontifical Gregorian University in Rome where he implemented Leo XIII's (r.1978-1903) demand for an emphasis upon Thomistic theology. He also served as a consultor for the Congregation of the Index, a role that called for a careful reading of books denounced as either theologically rash or heretical and participation in discussions resulting in decisions forwarded to the pope. Wernz was a consultor for the cases of Dalmace Leroy (1828-1905) in 1895 and John Zahm (1851-1921) in 1898.4 In both instances the primary point at issue was human evolution from

2 Pontifical Biblical Commission, De charactere historico trium priorum capitum Geneseos, Concerning the Historical Nature of the First Three Chapters of Genesis (June 30, 1909). For the original Latin text: http://www.vatican.va/roman_curia/congregations/cfaith/pcb_ documents/rc_con_cfaith_doc_19090630_genesi_lt.html or an English translation by E. F. Sutcliffe, S.J.: http://www.catholicapologetics.info/scripture/oldtestament/commission.htm (accessed October 5,2019 ).

3 Richard Puza, "Franz Xaver Wernz: Lehrer, Kanonist und Jesuitengeneral aus Rottweil," Theologische Quartalschrift 174, no. 1 (1994): 22-33.

4 Mariano Artigas, Thomas Glick, and Rafael Martínez, Negotiating Darwin: The Vatican Confronts Evolution 1877-1902 (Baltimore: Johns Hopkins University Press, 2006), esp. 85-91 and $15^{2-53}$. 
non-human ancestors. In 1891, Leroy had published his L'Évolution restreinte aux espèces organique (Evolution restricted to organic species). The sole Jesuit cardinal participant in the congregation decision to condemn the book was Camillo Mazzella (1833-1900), who had resolutely rejected evolution in his 1877 neo-Scholastic textbook De Deo creante (On God the creator). ${ }^{5}$ Consultor Luigi Tripepi's report on Leroy was very negative, especially on the issue of the origin of the human body. Tripepi relied heavily upon Mazzella's textbook, including references to Aquinas's teaching that animal reproduction does not yield new species. Secretary Cicognani wrote an additional memorandum and again emphasized the problematic issue of the descent of the human body from non-human ancestors, writing that "the evolutionist system is impudent and anti-Christian, particularly when applied to the body of man." ${ }^{1}$ In Leroy's subsequent retraction, human evolution was the only topic mentioned as unacceptable to the Vatican authorities.

Leroy had in fact never explicitly defended a detailed thesis on the evolutionary origins of the human body. He had proposed several hypothetical scenarios and suggested that the church had not offered a clear doctrinal statement that excluded them. The hypothesis he preferred was that evolutionary processes might produce a body that would only become a human body when conjoined with a human soul, the substantial form that rendered it truly human. On this account, evolution did not produce the first human body that awaited infusion of a soul. Rather, the first human body only existed as a composite of body and soul when soul was introduced by God into a "substrate" that was the result of evolution. However, because theological consensus prohibited two substantial forms coexisting in the same body, the substrate could not have an animal soul unless it was in some way subsequently replaced by a human soul. Leroy's hypothetical discussion was frowned upon by members of the Congregation, and Wernz was a party to the decision to condemn.

The 1898 John Zahm case came to a similar resolution, again with Wernz as one of the consultors. Criticism of Zahm's 1896 Evolution and Dogma was particularly severe among Jesuits writing in their journal La Civiltà cattolica based in Rome. In his denunciation of Zahm's book, Archbishop Otto Zardetti (19471902) noted that in De Deo creante Mazzella had theologically refuted the position put forward by both Zahm and Leroy. Consultor Buonpensiere went much further and proposed an action more appropriate to the Holy Office, a condemnation of the assertion that "God did not make the body of Adam

5 John Ciani, "Cardinal Camillo Mazzella, S.J.," in Varieties of Ultramontanism, ed. Jeffrey von Arx (Washington, DC: Catholic University of America Press, 1998), 103-17.

6 Artigas, Glick, and Martínez, Negotiating Darwin, 9o-91. 
immediately from the mud of the earth, but out of the body of an anthropomorphic brute, which had been prepared to be produced by the forces of natural evolution from lower matter."7 Although Buonpensiere's proposal was not adopted, it was included in the report discussed at the meeting where the decision was made to recommend prohibition of further publication of Zahm's book. Because congregation deliberations were not made public, Xaver Wernz was one of a privileged few who fully understood how objections to human evolution predominated within the highest reaches of the Vatican curia.

\section{Erich Wasmann: Natural Species and Polyphyletic Evolution}

One prerequisite for avoiding superficial discussions of theological tension with respect to science is to avoid reification of concepts or institutions into agents. Actual confrontations and negotiations take place between individuals, not between abstractions or collectives such as religions, religious orders, ideologies, or scientific research programs. In this respect, the career of Erich Wasmann offers a pertinent case study. Although the idea that life evolved from a small set of primordial forms of unknown origin was not unusual during the nineteenth century, it was tightly circumscribed by influential members of the German scientific community such as Ernst Haeckel (1834-1919). Wasmann reacted by making a centerpiece of his synthesis of evolution and Catholicism the idea that, although there are extensive lineages of evolutionary descent, these lineages began through divine production of an unknown number of natural species without ancestry.

Wasmann was born in the Austrian town of Meran in the auspicious year of 1859. He was educated by Benedictines in Meran, Franciscans in Hall, and then at the Jesuit college Stella Matutina in Feldkirch. ${ }^{8}$ In 1875 , he entered the Jesuit novitiate in Exaten where a formation house had been founded in the Netherlands shortly after the 1872 Jesuit Law expelled the Jesuits from Germany. His

7 Artigas, Glick, and Martínez, Negotiating Darwin, 151.

8 For discussion of Wasmann and further references, see Heike Baranzke, "Erich Wasmann (29.5.1859-27.2.1931): Jesuit und Zoologe in Personalunion," Jahrbuch für Geschichte und Theorie der Biologie 6 (1999): 77-140; Abigail Lustig, "Ants and the Nature of Nature in Auguste Forel, Erich Wasmann, and William Morton Wheeler," in The Moral Authority of Nature, ed. Lorraine Daston and Fernando Vidal (Chicago: University of Chicago Press, 2004), 282-307; Klaus Schatz, "Pater Erich Wasmann SJ und die Humanevolution: In memoriam Pater Rainer Koltermann SJ (†5. Juli 2009)," Theologie und Philosophie 85, no. 1 (2010): 81-86; Robert Stumper, "Deux grandes figures de la science des insectes sociaux E. Wasmann et A. Forel," Insectes sociaux 1, no. 4 (1954): 345-69. 
Scholastic training in philosophy took place in Afferden, where Tilmann Pesch (1836-99) taught at Bleijenbeek Castle. Pesch's textbook included an extensive neo-Scholastic critique of evolutionary topics; Wasmann would retain a Thomistic framework during his later efforts to classify life forms in distinct categories of plant, animal, and human. ${ }^{9}$

Due to Wasmann's precarious respiratory health, he was ordained relatively early in his Jesuit formation in 1888 . He never completed a doctoral dissertation, but during 1890 and 1891, he studied biology for three semesters with Berthold Harschek (1854-1941) and Karl Isidor Cori (1865-1954) at the German University in Prague. Wasmann's poor health motivated his assignment to research rather than the missions or teaching responsibilities. He worked in Luxembourg between 1890 and 1911 and then at the newly constructed Saint Ignatius College in Valkenburg in the Netherlands. In addition to his own research he edited the Jesuit journal Stimmen aus Maria-Laach.

Building upon the research habits he had developed since childhood, Wasmann became an entomologist of international repute. The present essay is not the place to analyze his extensive contributions to entomology and animal psychology, except to note that his most detailed case studies in support of evolutionary descent were drawn from his work with myrmecophile beetles, especially from the order Staphylinidae, in which ancestral species evolved to become parasitic on ants and then termites. In addition to discovering hundreds of species and amassing enormous collections of ants, beetles, and termites, Wasmann developed broader interests in evolutionary theory and its implications for taxonomy. Wasmann's associates in Northern Europe were generally more receptive to evolutionary theory than was the case within the editorial offices of the La Civiltà cattolica in Rome. Articles in Stimmen aus Maria-Laach often emphasized the viability of descent with modification except for the special case of humanity. Wasmann turned his attention to evolution in a series of articles in 1903 and developed them into his Die moderne Biologie und die Entwicklungstheorie. ${ }^{10}$ Before considering some of Wasmann's ideas in detail, it will be useful to summarize the sequence of events during the crucial decade after 1903 .

9 Tilmann Pesch, Institutiones Philosophiae naturalis secundum principia S. Thomae Aquinatis ad usum scholasticum (Freiburg: Herder, 1880), 612-78.

10 Erich Wasmann, Die moderne Biologie und die Entwicklungstheorie (Freiburg: Herdersche Verslagshandlung, 1904). There were two 1904 editions and a third in 1906 that was translated into English: Erich Wasmann, Modern Biology and the Theory of Evolution, trans A. M. Buchanan (London: Kegan Paul, Trench, Trübner \& Co., 1910). 
Wasmann's 1904 book elicited a scathing response from Ernst Haeckel both in print and in public lectures in 1905. Wasmann responded with an expanded 1906 edition and public lectures of his own in Berlin in 1907. The lectures were widely publicized and transcriptions with commentary were published in multiple formats. In 1908, Wernz intervened and sent Wasmann a warning letter concerning human evolution. By that point, Wasmann may very well have already submitted the evolution article that would appear in The Catholic Encyclopedia in 1909. It was also in 1909 that the Pontifical Biblical Commission issued its decree regarding Genesis 1-3. Wasmann composed a set of private notes summarizing his assessment of the decree's import and, in 1910, he published the English translation of Die moderne Biologie (Modern biology). Finally, in 1912, Wasmann responded to a harsh critique from Simon FitzSimons (1848-1928) and composed a set of "Jugenderinnerungen," reflections on his childhood and his relationship with his father in particular.

Throughout his career, Wasmann argued for the necessity of divine intervention in three instances where scientific evidence was inconclusive: the origin of life, the origin of a discrete set of natural species unrelated through a common ancestor, and the origin of the spiritual aspect of humanity, the human soul. He defended his position both in print and in numerous public events, most famously in three highly publicized lectures at the cavernous Sing-Akademie concert hall in Berlin during February of 1907, followed by a fourth meeting featuring Wasmann's response to no less than eleven critics. ${ }^{11}$ Over one thousand people attended each session, resulting in extensive coverage in both the scientific and popular press. Wasmann's monist critics objected to his skepticism about universal common descent and the explanatory power of natural selection, but they more frequently attacked him as a prevaricating theist and an untrustworthy and obfuscating Jesuit.

In both the secular and the Catholic press, the consensus was that Wasmann was victorious from a scientific perspective and that his opponents had mostly resorted to ad hominem attacks on his religious beliefs. The satirical magazine Kladderadatsch captured this aspect of the confrontation in a 1907 cartoon of

11 Both Wasmann and Ludwig Plate (1862-1937) published transcriptions with commentary. Erich Wasmann, The Berlin Discussion of the Problem of Evolution: Full Report of the Lectures Given in February, 1907 and of the Evening Discussion (London: Kegan Paul, Trench, Trübner \& Co., 1909). Ludwig Plate, Ultramontane Weltanschauung und moderne lebenskunde Orthodoxie und Monismus: Die Anschauungen des Jesuitenpaters Erich Wasmann und die gegen ihn in Berlin gehaltenen Reden (Jena: G. Fischer, 1907). Three 1909 Innsbruck lectures were also included in Erich Wasmann, Modern Biology and the Theory of Evolution, 484-522. See Robert Richards, The Tragic Sense of Life: Ernst Haeckel and the Struggle over Evolutionary Thought (Chicago: University of Chicago Press, 2008), 356-71. 


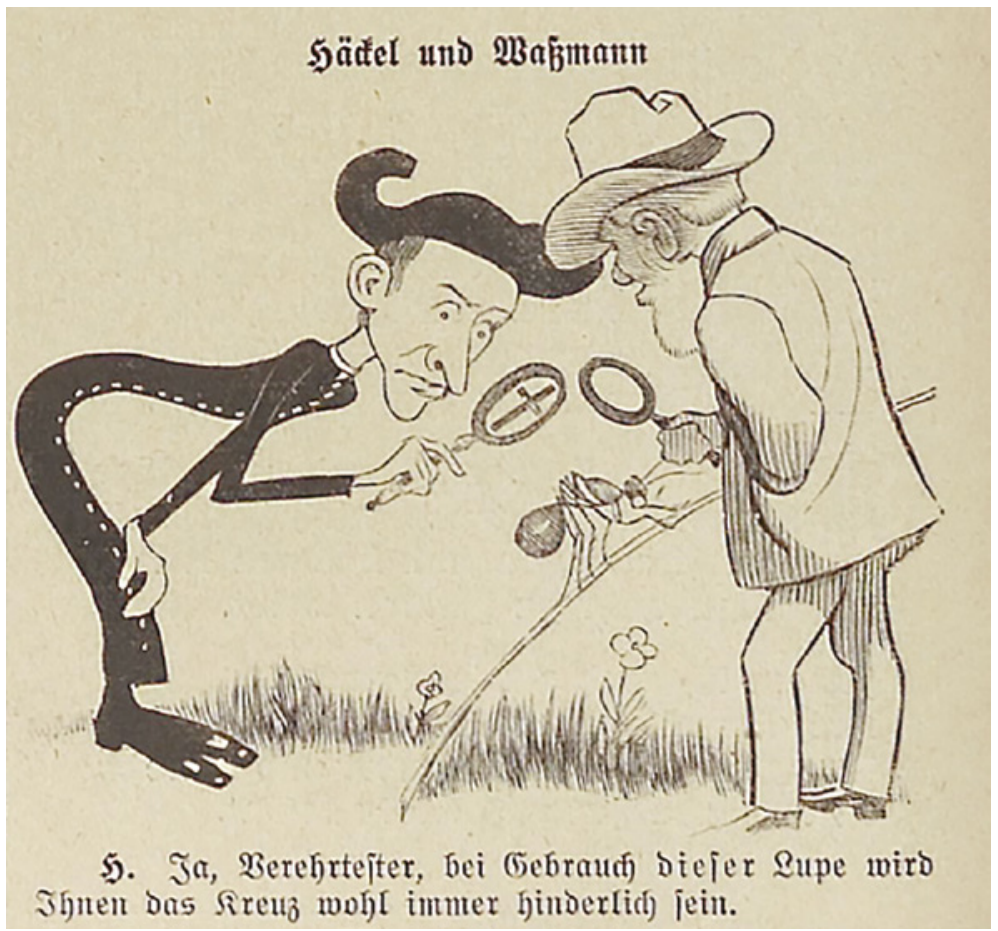

FIGURE 6.1 Haeckel and Wasmann Haeckel: "Yes, dear fellow, by using that glass, the cross is always going to get in the way" (Kladderadatsch 6o, no. 10 [March 10, 1907]:38)

Haeckel and Wasmann inspecting an ant with Wasmann's view obstructed by a cross.

Wasmann's sphere of influence expanded through his participation in The Catholic Encyclopedia project. Although the encyclopedia was American in inspiration, many of the articles were commissioned from European scholars. This was the case for the two articles on evolution written by Wasmann and his fellow Jesuit Hermann Muckermann (1877-1962). Wasmann and Muckermann divided their responsibilities for the project with Wasmann contributing a relatively short introductory synopsis in which he concisely summarized the central points of his position. ${ }^{12}$ Some of Wasmann's terminology was drawn from Haeckel's introduction of the terms "monophyletic" and "polyphyletic" in

12 Erich Wasmann, "Evolution: The Attitude of Catholics towards the Theory," in The Catholic Encyclopedia: An International Work of Reference on the Constitution, Doctrine, Discipline, and History of the Catholic Church, ed. Charles G. Herbermann et al., (New York: Robert Appleton, 1907-14), 5:654-55. 
connection with the hypothesis that all life is descended from a single origin and thus is a monophyletic tree of descent. Wasmann resolutely rejected this conclusion and insisted that only a polyphyletic conception of evolution was convincingly supported by empirical evidence:

There is, in fact, no evidence whatever for the common genetic descent of all plants and animals from a single primitive organism. Hence the greater number of botanists and zoologists regard a polygenetic (polyphyletic) evolution as much more acceptable than a monogenetic (monophyletic). At present, however, it is impossible to decide how many independent genetic series must be assumed in the animal and vegetable kingdoms. This is the gist of the theory of evolution as a scientific hypothesis. It is in perfect agreement with the Christian conception of the universe; for Scripture does not tell us in what form the present species of plants and animals were originally created by God..$^{13}$

To support his assertion that his polyphyletic version of descent was scientifically motivated, Wasmann frequently cited agreement from the scientific literature. In a 1909 lecture in Innsbruck, he mentioned the paleontologist Melchior Neumayr (1845-90) as one who had introduced the idea of natural species into paleontology using different terminology:

A natural species consists of the members of one series of forms, connected phylogenetically by descent. This definition of the natural species was given by Neumayr many years ago, and so it is by no means an invention of theologians, as the monists constantly assert. It is true that Neumayr spoke of "palaeontological", and not of "natural" species, but he meant exactly the same thing. ${ }^{14}$

Neumayr had published extensively on the invertebrate fossil record, especially fresh water snails, and, in an 1875 publication, he included detailed illustrations of his observations and proposed a tentative phylogeny based upon

\footnotetext{
13 Erich Wasmann, "Evolution," 654.

14 Erich Wasmann, Modern Biology and the Theory of Evolution, 488. Wasmann used "systematic and natural species" as translation for "systematische und natürliche Art." He noted that Tilmann Pesch had used similar terminology in his discussion of evolution in the second edition of his textbook. See Wasmann, Modern Biology and the Theory of Evolution, 296, and Tilmann Pesch, Institutiones Philosophiae naturalis secundum principia S. Thomae Aquinatis ad usum scholasticum (Freiburg: Herder, 1897), 2:335.
} 
continuous development preserved in the fossil record. ${ }^{15}$ Wasmann thus could add Neumayr's data to his own research on inquiline beetles as documented cases of descent with modification. But Wasmann also emphasized that although each of these lineages plausibly had an ancient ancestor, there was no convincing evidence for an even earlier common ancestor for them all. He acknowledged that both the number and the times of origin of these independently evolving natural species were unknown, and he projected that they might very well never be known. Wasmann proposed divine intervention only for the inception of these natural species that he was loath to identify except in the case of humanity:

God does not interfere directly with the natural order when He can work by natural causes: this is a fundamental principle in the Christian account of nature, and was enunciated by the great theologian Suarez, whilst St. Thomas Aquinas plainly suggested it long before, when he regarded it as testimony to the greatness of God's power, that His providence accomplishes its aims in nature not directly, but by means of created causes. ${ }^{16}$

He also emphasized that natural species do not arise through creation $e x$ nihilo, but via divine production from predisposed matter. He remained noncommittal about the relationship of natural species to biblical kinds:

But we must not read this idea of species into the biblical account of the creation, as if it really occurred there. We can only say that, if this idea of kind is confirmed, it will be additional testimony to prove that the biblical account of the creation does not contradict the facts ascertained by science. ${ }^{17}$

Natural species have diversified over time, resulting in both extinct and extant "systematic species." In contrast to his agnosticism about the identity of natural species, Wasmann was explicit about examples of systematic species descended from a common ancestor:

15 Melchior Neumayr and C. M. Paul, "Die Congeriene und Paludinenschichten Slavoniens und deren Faunen: Ein Beitrag zur Descendenzetheorie," Abhandlungen der KaiserlichKöniglichen geologischen Reichsanstalt 7 (1875): 1-106.

16 Wasmann, Modern Biology and the Theory of Evolution, 274.

17 Wasmann, Berlin Discussion, 18. 
As examples of systematic species I may mention the lion, the tiger, and the jaguar within the genus felis. The characteristics distinguishing the species are essential only in the empiric and not in the philosophical sense. For this reason some scientists subsequently introduced the idea of natural species, comprising groups, varying in size, of systematic species. ${ }^{18}$

Wasmann was always careful to distinguish the idea of descent with modification from both "Darwinism" as a materialist ideology and Darwin's theory of selection. Darwinian theory in the latter sense included reliance upon natural selection as the chief cause of evolutionary change. Wasmann consistently rejected exclusively Darwinian evolution due to what he perceived as its scientific weaknesses. He complained that natural selection could not fully account for variation that turns out to be adaptive by mere chance and that the fossil record does not preserve a "chaos of imperceptibly slight variations, such as the theory of selection requires."19 Wasmann's emphasis on the causal power of an "interior capacity" or "interior laws" independent of natural selection was not unusual during an era that historian Peter Bowler has labelled the "eclipse of Darwinism." 20 On these interior laws Wasmann commented only that "this much, however, we can say about their nature, that they depend upon the chemico-physical constitution of the organism in intimate association with its teleological principles of development, which latter are in scholastic philosophy aptly designated as 'formae substantiales' or 'entelechies."'21

Wasmann clearly accepted Catholic doctrine regarding the human soul; he did make some brief allusions to Aquinas's (1225-74) discussion of the transition to the individual human soul during embryological development:

Whilst I am dealing with this subject, I may refer also to the opinion of St. Thomas Aquinas regarding the succession of substantial forms of being in the ontogeny of man, and this from the purely philosophical standpoint, to some extent reveals a possibility of accepting a preformation of the first human body by way of evolution. ${ }^{22}$

\footnotetext{
18 Wasmann, Berlin Discussion, 5.

19 Wasmann, Modern Biology and the Theory of Evolution, 260.

20 Peter Bowler, The Eclipse of Darwinism: Anti-Darwinian Evolution Theories in the Decades around 1900 (Baltimore: Johns Hopkins University Press, 1983).

21 Erich Wasmann, The Rev. Simon FitzSimons' Ideas on Evolution: A Reply to "Revised Darwinism, or Father Wasmann on Evolution, by the Rev. Simon FitzSimons” (St. Louis: Herder, 1912), $31-32$.

22 Wasmann, Modern Biology and the Theory of Evolution, 440.
} 
Although Wasmann considered the empirical evidence for evolution of the human body to be inconclusive, in one of his Berlin lectures, he made a point of asserting that even if it was shown in the future that the human body had definitely descended from non-human ancestors, this would not contradict Catholic doctrine. Here, he took a position very similar to the one Leroy had hypothetically suggested in 1891, namely, that

man would have become man completely only when the organized matter had so far developed through natural causes, as to be capable of being animated with a human soul. The creation of the first human soul marks the real creation of the human race, although we might assume that a natural development lasting millions of years had preceded it."23

It was at this point in Wasmann's deliberations that two interventions ended his publications on this topic. First, on March 18, 1908, less than two years after his election as Jesuit superior general, Wernz wrote Wasmann a cautionary letter. He insisted that the descent of the human body from non-human ancestors was not an acceptable Catholic position and should not even be discussed hypothetically for fear of inducing confusion in the minds of the faithful. ${ }^{24}$ Wernz clearly had absorbed the mentality that prevailed within the Congregation of the Index, during the Leroy and Zahm condemnations. He expected Wasmann to drop all philosophical or theological speculations about human evolution from any future editions of Die Moderne Biologie und die Entwicklungstheorie. Wasmann decided instead to forego any further editions although English and Italian translations of the 1906 edition did proceed. ${ }^{25} \mathrm{He}$ also declined the position he was offered as chair of zoology at the new Frankfort University because of the stipulation that he would have to withdraw from the Jesuits. ${ }^{26}$ After this point, he restricted his writing either to purely scientific or devotional genres or to tracts in opposition to Haeckel's monism. For example,

\footnotetext{
23 Erich Wasmann, The Berlin Discussion, 51.

24 Klaus Schatz, "Pater Erich Wasmann," 84-85. Schatz gives the archival location of Wernz' letter as Archivum Romanum Societatis Jesu, Rome, Registro Lettere dei Generali, Germaniae VII, $121 \mathrm{f}$. Schatz also provides excerpts from Wernz's letters to Wasmann's provincial superior, Ernst Thill (1857-1921).

25 The Italian translation by Agostino Gemelli (1878-1959), was highly edited with the translator's commentary. Some of Wasmann's notes for correspondence with him are transcribed in Heike Baranzke, "Erich Wasmann," 127-31.

26 Hermann Schmitz, "In Memoriam P. Erich Wasmann S. J.," Tijdschrift voor Entomologie 75 (1932): 1-57, at 19. Also see Stumper, "Deux grandes figures," 348.
} 
in his 1919 Der christliche Monismus (Christian monism), he avoided evolutionary topics altogether.

The second factor that discouraged Wasmann's exploration of human evolution was the 1909 decree on Genesis by the Pontifical Biblical Commission. The decree posed a series of dubia, theses for which it provided either positive or negative judgments without commentary. The document began in a conservative key requiring that the Genesis creation account generally be taken in a "literal historical sense": "Do the various exegetical systems excogitated and defended under the guise of science to exclude the literal historical sense of the first three chapters of Genesis rest on a solid foundation? Answer: In the negative." ${ }^{27}$ The Commission's response was also negative for the third dubium that touched on several points relevant to human origins:

In particular may the literal historical sense be called in doubt in the case of facts narrated in the same chapters which touch the foundations of the Christian religion: as are, among others, the creation of all things by God in the beginning of time; the special creation of man; the formation of the first woman from the first man.

Historian Heike Baranzke has published a transcription of Wasmann's undated personal notes on the decree. Wasmann began by noting that, as had been the case with the 1616 decree against Copernican astronomy, the present decree was revocable. Perhaps in the expectation that it would indeed eventually be revoked, he noted the distinction between internal and external modes of assent:

The internal submission which the decree requires of us is not an act of faith (through which we hold something as true fide divina, since it is revealed by God). It further demands, not an unconditional, but only a conditional belief in the contents of the decree. It is, expressed positively, an internal act of divine veneration (religio), a willing submission of our intellect to the teaching authority of the Church as an institution instated by God, and indeed an act of limited strength. While it requires firm consent, it nevertheless is curtailed by two important restrictions, the first being more general and the second of a more specific nature. The first restriction applies to all and reads: "I hold it as true until the teaching

27 All the following English translations from the decree are by E. F. Sutcliffe, S.J., available at: http://www.catholicapologetics.info/scripture/oldtestament/commission.htm (accessed October 4, 2019). 
profession of the Church decides otherwise". The second restriction depends on one's level of knowledge: if he as an expert has sound evidence against the objective correctness of the decree, he has no obligation of internal consent to its truth, but nevertheless the obligation of obedient silence (silentium obsequiosum), which already pertains to external submission. ${ }^{28}$

It would appear that Wasmann was dubious about the "objective correctness of the decree" and placed himself in the category of an expert under the "obligation of obedient silence." In his comments on the third dubium, we find him parsing the decree's passages on human origins in some detail:

It should be further noted that among the facts enumerated as being very closely aligned with the foundation of the Christian religion in Dubium III, indeed the "peculiaris creatio hominis" is found, but not the formatio Adae ex limo terrae and not even the peculiaris creatio corporis humani. Further, it contains the "formatio primae mulieris ex primo homine" but not the formatio Evae ex costa Adae, etc. Indeed, the Biblical Commission, no doubt intentionally, has expressed itself very cautiously here. ${ }^{29}$

Although Wasmann was pleased that the decree mentioned neither the creation of Adam from the slime of the earth nor the creation of Eve from Adam's rib, he was still confronted by a requirement to adhere to a distinctive creation of humanity (peculiaris creatio hominis). In one respect, this was not too oppressive since Wasmann did not feel that available scientific evidence warranted definitive conclusions about pre-human ancestry. Nevertheless, he wanted to argue proactively that even if such evidence became convincing in the future, it would not contradict properly understood Catholic doctrine. Here, he was silenced by the directive from his superior general.

Given this state of affairs, it was both annoying and frustrating when FitzSimons attacked Wasmann on the theological front in a 1910 critique of his Berlin

28 Baranzke, "Erich Wasmann," 123-26, at 123. I am indebted to Andrea Patterson for aid in translating Wasmann's German. The phrase he used for silentium obsequiosum was "gehorsamen Schweigen." Debate over this concept goes back to at least 1705 when in his Vineam Domini Sabaoth Clement XI (r.170o-21) declared the French Jansenist reliance upon "silence respectueux" to be a deceptive form of disbelief. Obsequium was also a controversial concept during discussions of the 1870 proclamation of papal infallibility. 
lectures. ${ }^{30}$ His theological point was buried toward the very end of a longwinded polemic replete with glaring misinterpretations and scientific errors. FitzSimons objected to virtually every aspect of Wasmann's views on evolution, misunderstanding most of them in the process. But he did raise a valid theological point about Wasmann's incomplete discussion of the transition from an animal soul to that of a human:

According to the teaching of St. Thomas and all Christian philosophers the soul is the first principle of life - "primum principium vitae". According to Father Wasmann's hypothesis this first principle of life is introduced into an organized being already endowed with the life principle. Consequently in Father Wasmann's man there are of necessity two principles of life, one the original life of the incomplete man, the other the human soul specially created. Now how do these two principles of life existing within each of us act? Do they operate separately or conjointly? It is hardly conceivable that the first life principle is absorbed by the second, and it is equally improbable that it is annihilated by the second or by God to make room for the second. ${ }^{31}$

With remarkable patience, Wasmann painstakingly corrected many of FitzSimons's trivial scientific blunders and interpretive errors. He did not address the more interesting theological issue FitzSimons had raised. He cited sheer exhaustion as an excuse, but he may have simply been conforming to Wernz's private prohibition. ${ }^{32}$ Overblown as FitzSimons's rhetoric was, he had called attention to a theological issue that would persist throughout the twentieth century, especially among Thomists. How can the introduction of a novel human substantial form be incorporated into a gradual process of physical evolution?

After 1908, Wasmann became mute on this topic in favor of "obedient silence." What was his state of mind at this juncture? One source of evidence is the set of "Jugenderinnerungen" he composed in 1912 shortly after his move from Luxembourg to Valkenburg. ${ }^{33}$ There, he reflected upon his childhood and

30 Simon FitzSimons, "Father Wasmann on Evolution," The American Catholic Quarterly Review 35 (1910): 12-48. FitzSimons, Revised Darwinism, or, Father Wasmann on Evolution (New York: P. J. Kennedy, 1910).

31 FitzSimons, Revised Darwinism, 49.

32 Wasmann, The Rev. Simon FitzSimons' Ideas on Evolution, 46.

33 These 1912 recollections were published posthumously in 1932. Erich Wasmann, "Jugenderinnerungen," Stimmen der Zeit 123 (1932): 110-19, 191-99, 258-68, 327-34, 407-13. 
adolescent relationship to his parents and especially his father. A pervading theme is the sense of guilt he still felt for his chronic failure to appreciate his father's nobility of character. He attributed his lack of perception to the glaring disparity between his childish arrogance and intellectual pride in contrast to his father's patient piety and humility. It is plausible to infer that Wasmann's guilty conscience helped cement his loyalty to the Jesuits, especially after his father's death in 1886. This is also suggested by the background for his choice of a Jesuit vocation. In gratitude for his survival of a childhood accident when he was two years old, his parents had taken a vow concerning his entry into the Jesuits. Wasmann does not provide the exact content of the vow, writing only that it was fulfilled upon his entry into the order and that he was not told about it until then. ${ }^{34}$ At that point his father also informed him that when he converted to Catholicism, he had wanted to become a Jesuit himself but was counseled by his spiritual advisor to forego that vocation in the hope that his son would adopt it. Wasmann's humble submission to his Jesuit superiors thus served as penance for his earlier abrasive ridicule of his father. Superior General Wernz's directive offered him a belated opportunity to emulate his father's humility and forego claims to intellectual superiority, a motivation that could only have amplified the strength of his Jesuit vow of obedience. Further analysis of the psychological factors in his decision to maintain obedient silence would benefit from comparison to other clerics such as Leroy or Henry de Dorlodot (1855-1929) who were faced with similar decisions. Although Wasmann did remain silent about possible theological implications of human evolution, his discussions of natural species and polyphyletic evolution would leave an extensive legacy for several decades.

\section{3}

\section{Wasmann's Legacy}

Wasmann's influence as an evolutionary theorist was most obvious in the work of his colleague Hermann Muckermann (1877-1962). German born, Muckermann entered the Jesuits in 1896 and studied philosophy at the College of the Sacred Heart in Wisconsin. He regularly corresponded with Wasmann and relied upon his research to draw a distinction between animal instinct and human intelligence. ${ }^{35} \mathrm{In} 1906$, he published a spirited polemic in which he

\footnotetext{
34 Wasmann, "Jugenderinnerungen," 194 and 408.

35 Hans Ebert, "Hermann Muckermann: Profil eines Theologen, Widerstandskämpfers und Hochschullehrers der Technischer Universität Berlin," Humanismus und Technik 20 (1976): 29-40.
} 
followed Wasmann's lead by being skeptical of the explanatory power of natural selection, sharply critical of Haeckel's monism, and dubious about the descent of humanity from non-human ancestors. He also agreed with Wasmann about the theological viability of evolutionary descent from created progenitors:

it is a matter of perfect indifference, as far as faith is concerned, to maintain that the species of plants and animals, now existing, were originally created by God in their present state, or to hold an original creation of a few species which possessed the power of developing into others. ${ }^{36}$

In his 1909 Catholic Encyclopedia article, Muckermann used Wasmann's discussion of the Dinarda genus of beetles to illustrate gradual evolutionary change from one systematic species to another, but he also concluded that paleontological evidence is lacking for the origins of major groups such as vertebrates, mammals, or birds. Muckermann also distinguished among the biological, scriptural, and philosophical senses of species. "The concept, therefore, of species according to Holy Scripture, Philosophy, and Science, is by no means a synonymous one for the natural units of the organic world. And particularly, the first chapter of Genesis should not be brought into connexion with Linnaeus's 'Systema naturae." 37 Muckermann agreed with Wasmann that the determination of the independent "natural units of the organic world" is an empirical problem and that polyphyletic evolution is preferable to universal common descent. He made only a brief comment about the kinds mentioned in Genesis:

The enumeration of certain popular groups of organisms such as fruittrees, draft-animals, and the like, could have no other design than to manifest to the simplest as well as to the most cultivated mind the action of the Creator of all things; at least, there can be no question of a scientific conception of genera and species. ${ }^{38}$

36 Hermann Muckermann, Attitudes of Catholics Toward Evolution and Darwinism (St. Louis, MO: Herder, 1906), 82.

37 Hermann Muckermann, "Evolution: History and Scientific Foundations," in The Catholic Encyclopedia: An International Work of Reference on the Constitution, Doctrine, Discipline, and History of the Catholic Church, ed. Charles G. Herbermann et al. (New York: Robert Appleton, 1907-14), 5:655-70, at 660.

38 Muckermann, "Evolution," 66o. 
Muckermann consistently stayed within the expectations of the Biblical Commission's 1909 guidelines for acceptable interpretation of Genesis, but he also incorporated the concept of evolving natural species into a high-profile Catholic publication, The Catholic Encyclopedia.

Many other examples of Wasmann's legacy are available in Catholic neoScholastic pedagogical literature. For example, Joseph Gredt's teaching manual, Elementa Philosophiae Aristotelico-Thomisticae (Elements of AristotelianThomistic philosophy), was widely used in Catholic seminaries throughout the world. ${ }^{39}$ Gredt unequivocally rejected monophyletic Darwinian evolution while acknowledging that Wasmann, among others, had presented good arguments for the plausibility of polyphyletic evolution. Gredt also recognized the natural species concept and agreed with Wasmann that the identification of natural species falls within the context of empirical biology ${ }^{40}$ Gredt's text was an influential factor in the training of Catholic clergy throughout the first half of the twentieth century.

Similarly, in 1934, Richard Percival Phillips authored another widely used textbook in the Thomistic manual tradition..$^{41}$ Until his retirement in 1961, Phillips was for many years a philosophy instructor at St John's Seminary in Wonersh, Surrey. In his chapter on transformism, he argued that plants, animals, and humanity are the only natural species that can be asserted with metaphysical certainty. Because Phillips preferred to define natural species metaphysically by means of their alleged essence, he was less optimistic than Wasmann about identifying them empirically. He also was less willing than Wasmann to accept significant evolutionary change, writing, for example,

39 Joseph Gredt, Elementa philosophiae Aristotelico-Thomisticae, 13th ed. (Freiburg: Herder, 1961). Born in Luxembourg, Gredt (1863-1940) was an ordained Benedictine and taught philosophy at St. Anselm's College in Rome beginning in 1896. The two volumes of his manual were initially published in 1899 and 1901. The first volume concluded with several sections on evolution that were expanded for later editions during the decade prior to Gredt's death. The text went through thirteen editions, the last in 1961.

40 See Gredt, Elementa philosophiae, 537. On the determination of natural species, Gredt writes: "Furthermore, in the genus plant and in the genus animal, we distinguish many natural species according to the stable type of organization, not only now, but even through geological periods. We must necessarily consider brutes and plants as supreme genera, which are further divided into diverse natural genera and species. It belongs to biology and not to philosophy to determine what these genera and species are" (Gredt, Elementa Philosophiae, 542; quoted in English translation in Mortimer Adler, Problems for Thomists: The Problem of Species [New York: Sheed \& Ward, 1940], 131-32).

41 Richard P. Phillips, Modern Thomistic Philosophy: An Explanation for Students, vol. 1: Philosophy of Nature (London: Burns, Oates, and Washbourne, 1934). 
that "the scientific evidence of the transformation of such natural species, as of reptiles into birds, seems to be by no means conclusive." Here, Phillips implied that reptiles and birds might constitute separate natural species "in the wider sense," but he did not press the point. ${ }^{42}$

As a last example, the Jesuit Anthony C. Cotter (1879-1954) was born in Bavaria, taught fundamental theology for twenty-nine years at Weston College in Massachusetts, and wrote extensively in the areas of biblical studies and apologetics. Cotter acknowledged Wasmann's distinction between systematic species and natural species, but also wrote rather petulantly that most of the arguments for evolution are "truly childish in their logic, props for wishful thinking." 43 His own metaphysical characterization of natural species was excessively teleological, and when he shifted to his own definition of biological species as groups created "for the same purposive activity," his examples were surprisingly simplistic: cows producing milk, bees producing honey, sheep producing wool. ${ }^{44}$ Cotter thus represents an example of a rather arrogant philosopher who inconsistently relied upon Wasmann's distinction between natural and systematic species while ignoring his arguments for significant evolutionary change.

These examples are only a small sampling from the extensive literature in which Wasmann's natural species gave structure to the polyphyletic evolution of systematic species. The degree to which this approached universal common descent depended upon the number of natural species assigned to divine intervention. There was an occasional tension between the contention of some philosophers such as Phillips or Cotter that the determination of natural species is a metaphysical topic, and the more common view advanced by Wasmann, Muckermann, and Gredt that this is an empirical question. In general, a detailed linkage of natural species to biblical kinds was not a point of emphasis; vague acknowledgment that there might be such a correlation satisfied the theological constraints of the time.

\section{$4 \quad$ Conclusion}

During the first half of the twentieth century, the concept of natural species was widely invoked to foster a synthesis of evolutionary biology with Catholic

\footnotetext{
42 Phillips, Modern Thomistic Philosophy, 342.

43 Anthony Cotter, Natural Species: An Essay in Definition and Classification (Weston, MA: Weston College Press, 1947), 218.

44 Anthony Cotter, Natural Species, 168.
} 
theology. Following Wasmann's lead, Muckermann, Gredt, Phillips, and Cotter all did so with varying degrees of acumen. The upshot in each case was a form of progressive creation, usually promoted under the rubric of polyphyletic evolution. The merits of this approach were twofold. During a theologically conservative era when biblical exegesis was expected to emphasize historical narrative and a prescribed theological tradition, polyphyletic evolution within natural species allowed for an imprecise but theologically prudent acknowledgment of biblical kinds, including humanity. Secondly, during that time period universal common descent was less supported by the available scientific evidence than the more easily documented lineages of polyphyletic evolution.

Both of these circumstances changed after 1950 and even more so after Vatican II when diverse biblical interpretations and non-Scholastic theology became more acceptable. In his $195^{\circ}$ encyclical, Humani generis, Pius XII (1876-1958) granted that the evolution of the human body was an appropriate topic for scientific research, but he also reinforced the doctrine of monogenism, the transmission of original sin through descent from a single pair of human ancestors. ${ }^{45}$ Scientifically informed theologians shifted their attention to discussions of the relative merits of monogenism and the empirically more viable idea of polygenism, the descent of modern humans from an ancestral population rather than one couple. Throughout the 196os population genetics and molecular data such as protein sequencing opened up powerful new sources of evidence for both universal common descent and the polygenetic evolution of Homo sapiens. ${ }^{46}$ Skepticism about monophyletic evolution had been eclipsed and in this new scientific and theological context Wasmann's concept of natural species was abandoned as no longer relevant. Among Catholics interested in theistic evolution, Adolf Haas (1914-1982) was one of the influential Jesuits who promoted the more process-oriented ideas of another Jesuit, Pierre Teilhard de Chardin (1881-1955).

45 Pius XII, 1950. Humani generis, paragraph 37; http://w2.vatican.va/content/pius-xii/ en/encyclicals/documents/hf_p-xii_enc_12081950_humani-generis.html (accessed October 5 , 2019).

46 Francisco Ayala, "Man in Evolution: A Scientific Statement and Some Theological and Ethical Implications," The Thomist 31 (1967): 1-20. 